\title{
PENGARUH SENAM BUGAR LANSIA TERHADAP KADAR HDL DAN LDL DI BPLU MANADO
}

\author{
${ }^{1}$ Stephany Sugeha \\ ${ }^{2}$ J. J. V. Rampengan \\ ${ }^{2}$ H. I. S. Wungouw
}

${ }^{1}$ Kandidat Skripsi Fakultas Kedokteran Universitas Sam Ratulangi Manado

${ }^{2}$ Bagian Fisiologi Fakultas Kedokteran Universitas Sam Ratulangi Manado

\begin{abstract}
The prevalence of decreased levels of High Density Lipoprotein (HDL) and elevated levels of Low Density Lipoprotein (LDL) in Indonesia is quite high, until increasing diseases such as stroke, dyslipidemia and Coronary Heart Disease (CHD). Gymnastic for elder is a form of exercise that moves easily followed by the elderly and can improve the health status. This study aimed to know about influence of gymnastic for elder to the levels of HDL and LDL before and after participating. This research is an experimental design with one group pre-post test. Subjects were 30 elderly people who are in Manado BPLU drawn from a population of 48 elderly people who met the inclusion criteria. Data analysis using a paired t-test with SPSS version 20.0. There are significant differences in levels of HDL $(p=0.022)$ and levels of LDL cholesterol $(p=0.000)$, before and after participating gymnastic for elder. Conclusion: Levels of HDL and LDL before and after doing SBL were significantly different.
\end{abstract}

Keywords: Gymnastic for elder, HDL, LDL

\begin{abstract}
Abstrak : Prevalensi penurunan kadar High Density Lipoprotein (HDL) dan peningkatan kadar Low Density Lipoprotein ( $L D L)$ di Indonesia cukup tinggi sehingga meningkatkan penyakit seperti stroke, dislipidemia dan Penyakit Jantung Koroner (PJK). Senam bugar lansia merupakan bentuk olahraga yang gerakannya mudah diikuti oleh lansia dan dapat meningkatkan status kesehatan. Penelitian ini bertujuan untuk mengetahui pengaruh Senam Bugar Lansia terhadap kadar $H D L$ dan $L D L$ sebelum dan sesudah mengikuti senam bugar lansia. Penelitian ini bersifat eksperimental lapangan dengan rancangan pre-post one group test. Subjek penelitian adalah 30 lansia yang berada di BPLU Manado yang diambil dari populasi yang berjumlah 48 lansia yang memenuhi kriteria inklusi. Analisis data menggunakan t-paired test dengan program SPSS versi 20.0. Terdapat perbedaan bermakna pada kadar $H D L(\mathrm{p}=0,022)$ dan kadar $L D L$ $(\mathrm{p}=0,000)$ sebelum dan sesudah mengikuti senam bugar lansia. Simpulan: Kadar HDL dan $L D L$ sebelum dan sesudah melakukan senam bugar lansia berbeda secara bermakna.
\end{abstract}

Kata kunci: Senam bugar lansia, $H D L, L D L$.

Di Indonesia, seseorang dianggap lansia (lanjut usia) pada usia 55 tahun. WHO (World Health Organization) menetapkan usia 60 tahun sebagai titik awal seseorang memasuki massa lansia. Biro Pusat Statistik (BPS) menggambarkan bahwa antara tahun 2005-2010 jumlah penduduk lanjut usia di Indonesia sekitar 19 juta jiwa atau 8,5\% dari seluruh jumlah penduduk. WHO memperhitungkan pada tahun 2025, Indonesia akan mengalami peningkatan jumlah warga lansia sebesar $41,4 \%$ yang merupakan sebuah peningkatan tertinggi di dunia. ${ }^{1}$

Berubah menjadi tua akan terjadi secara alamiah pada setiap orang. Hal ini menimbulkan berbagai masalah fisik, mental, sosial, ekonomi, dan psikologis. Fungsi fisiologis setiap organ tubuh berbeda-beda, namun pada umumnya fungsi fisiologis dari tubuh mengalami puncaknya 
pada umur antara 20 dan 30 tahun, setelah mencapai puncak fungsi alat tubuh akan berada pada kondisi tetap selama beberapa saat kemudian sedikit demi sedikit akan mengalami penurunan dengan bertambahnya umur. Angka kesakitan pada lanjut usia juga menunjukkan peningkatan setiap tahun dan timbul berbagai macam penyakit degeneratif. Perubahan yang kompleks pada lanjut usia sering menimbulkan masalah kesehatan, salah satunya adalah peningkatan kadar kolesterol darah. Kolesterol total dalam darah meningkat sejalan dengan proses penuaan. Peningkatan kolesterol tersebut mengalami plateu atau puncak pada usia kurang lebih 60 tahun pada pria, serta 70 tahun pada wanita. Prevalensi penurunan kadar High Density Lipoprotein (HDL) dan peningkatan kadar Low Density Lipoprotein ( $L D L)$ di Indonesia cukup tinggi, sehingga meningkatkan penyakit seperti stroke, dislipidemia dan Penyakit Jantung Koroner (PJK). Di seluruh dunia, kolesterol menyebabkan 4,4 juta kematian setiap tahunnya atau sekitar 7,9\% dari total angka kematian global. WHO memperkirakan lebih dari 50\% penyakit kardiovaskuler di Negara maju dapat dikaitkan dengan kadar kolesterol lebih dari 3,8 mmol/L. ${ }^{2}$

High Density Lipoprotein (HDL) adalah bentuk lipoprotein (lipid dan protein) dengan densitas lipoprotein tinggi yang dibentuk di usus dan hati. HDL seringkali dijuluki sebagai kolesterol baik. Menurut National Cholesterol Education Program Adult Panel (NCEP), kadar normal kolesterol $H D L$ yaitu lebih dari $40 \mathrm{mg} / \mathrm{dl}$. Lipoprotein densitas rendah (low-density lipoprotein, beta-2lipoprotein, $L D L$ ) adalah golongan lipoprotein (lemak dan protein) dengan densitas lipoprotein rendah yang dibentuk di hati dari hidrolisis VLDL (very low density lipoprotein) dan IDL (intermediate density lipoprotein). LDL seringkali disebut sebagai kolesterol jahat. Menurut NCEP, kadar normal kolesterol $L D L$ yaitu kurang dari $130 \mathrm{mg} / \mathrm{dl}^{3}{ }^{3}$

Berbagai strategi telah diupayakan untuk meningkatkan status kesehatan dan gizi lansia. Salah satunya adalah melalui aktivitas fisik dan olahraga yang sesuai dengan kondisi fisik lansia dan dilakukan secara teratur. Strategi tersebut diharapkan mampu mempertahankan kualitas hidup lansia agar tetap sehat dan bugar sepanjang hari. Senam adalah salah satu bentuk olahraga yang gerakannya mudah untuk diikuti oleh siapapun, termasuk lansia ${ }^{4}$.

Senam bugar lansia adalah senam aerobik low impact (menghindari loncatloncat), intensitas ringan sampai sedang, gerakan mudah dilakukan, gerakan tidak menimbulkan resiko cedera, gerakan harus bersifat ritmis, tidak terhentak-hentak, jarang merubah gerakan secara tiba-tiba ${ }^{5}$.

Beberapa penelitian membuktikan bahwa olahraga secara rutin dan teratur dapat meningkatkan kadar HDL dan menurunkan kadar $L D L$ dalam darah. Penelitian ini bertujuan untuk mengetahui bagaimana pengaruh senam bugar lansia terhadap kadar $H D L$ dan $L D L$.

\section{METODOLOGI}

Penelitian ini bersifat eksperimental lapangan dengan rancangan pre-post one group test. Penelitian dilakukan di BPLU Manado pada bulan November 2012 sampai Desember 2012. Subjeknya yaitu orang lanjut usia, pria maupun wanita yang berumur di atas 60 tahun (WHO) dan masih aktif beraktifitas fisik. Subjek penelitian diambil secara metode simple random sampling berjumlah 30 orang yang diambil dari populasi yang berjumlah 48 orang yang memenuhi kriteria inklusi dan telah mengisi informed consent. Alat dan bahan yang digunakan yaitu $C D$ atau kaset senam, tape atau $C D$ player, set pengukur kadar $H D L$ dan $L D L$ (peralatan Lab Patra), antikoagulan EDTA, alkohol 70\%, dan tabung sampel darah.

Variabel bebas pada penelitian ini adalah senam bugar lansia yang dilakukan secara rutin dan teratur yaitu tiga kali dalam seminggu (senin, selasa, dan kamis). Lamanya durasi senam yaitu 30 menit. Senam lansia menggunakan musik dan dipimpin oleh instruktur senam. Gerakangerakan senam disesuaikan dengan kondisi fisik dari para lansia yaitu gerakan berirama, 
mudah dilakukan, dan menghindari loncatloncat.

Variabel terikat pada penelitian ini adalah kadar serum kolesterol HDL dan LDL dalam darah. Pengambilan sampel darah dilakukan oleh petugas laboratorium setelah subjek berpuasa selama 8-12 jam. Analisis sampel darah dilakukan di laboratorium klinik menggunakan alat fotometer dengan metode enzymatic colorimetric test dan dinyatakan dalam satuan $\mathrm{mg} / \mathrm{dl}$. Deskripsi kadar kolesterol HDL dan $L D L$ ditentukan berdasarkan kategori dari NCEP, dimana untuk kategori kadar kolesterol $H D L$ dinyatakan menjadi kurang ( $<40 \mathrm{mg} / \mathrm{dl})$ dan tinggi $¥ 60 \mathrm{mg} / \mathrm{dl}$ ), sedangkan kategori kadar kolesterol $L D L$ dinyatakan menjadi optimal atau normal $(<100 \mathrm{mg} / \mathrm{dl})$, mendekati optimal (100-129 mg/dl), batas tinggi (130-159 mg/dl), tinggi (160-189 mg/dl), dan sangat tinggi ( $\geq 190 \mathrm{mg} / \mathrm{dl}$ ).

Semua data terolah kemudian dianalisis secara statistik menggunakan program Statistical Package for Social Science (SPSS) versi 20.0. Analisis univariat digunakan untuk mendeskripsikan setiap variabel yang diteliti. Kenormalan data variabel diuji dengan menggunakan OneSample Kolmogorov-Smirnov Test. Analisis multivariat diuji dengan t-paired test untuk menganalisis ada tidaknya perbedaan kadar $H D L$ dan $L D L$ sebelum dan setelah melakukan kegiatan senam bugar lansia beserta besarnya pengaruh dari senam bugar lansia terhadap kadar $H D L$ dan $L D L$.

\section{HASIL PENELITIAN}

\section{Deskriptif umur}

Dapat dilihat pada tabel tiga bahwa subjek yang terbanyak berumur 60-65 tahun.
Tabel 1. Deskriptif umur

\begin{tabular}{lll}
\hline No & $\begin{array}{l}\text { Umur } \\
\text { Subjek }\end{array}$ & Jumlah \\
\hline 1 & $60-65$ & 8 \\
2 & $66-70$ & 6 \\
3 & $71-75$ & 5 \\
4 & $76-80$ & 6 \\
5 & $81-85$ & 5 \\
\hline
\end{tabular}

\section{Deskriptif jenis kelamin}

Dapat dilihat pada grafik enam bahwa paling banyak subjek terdiri dari wanita (66,67\%) dibandingkan pria (33,33\%).

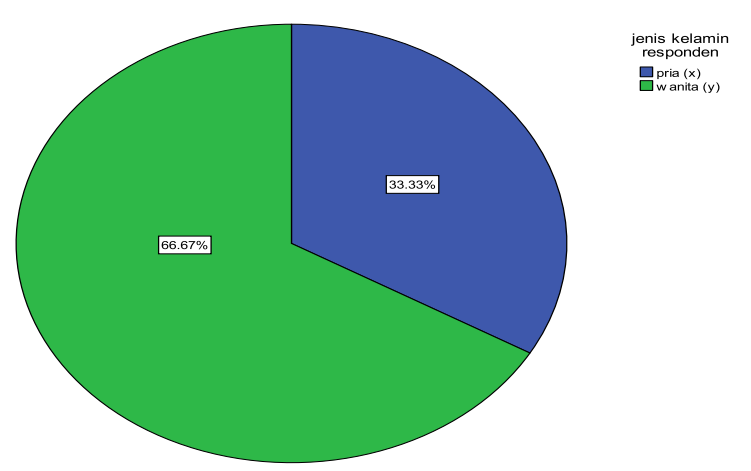

Gambar 1. Grafik deskriptif jenis kelamin

\section{Deskriptif kadar $H D L$ dan $L D L$}

Rata-rata kadar kolesterol HDL pada subjek lebih banyak mengalami peningkatan $(8,22)$ dibandingkan subjek yang mengalami penurunan $(3,33)$. Sedangkan pada rata-rata kadar kolesterol $L D L$, pada subjek lebih banyak mengalami penurunan $(51,40)$ dibandingkan subjek yang mengalami peningkatan $(8,37)$.

Tabel 2. Deskriptif kadar $H D L$ dan $L D L$

\begin{tabular}{|c|c|c|c|}
\hline \multicolumn{2}{|c|}{ Peningkatan } & \multicolumn{2}{|c|}{ Penurunan } \\
\hline$H D L$ & $L D L$ & $H D L$ & $L D L$ \\
\hline 8,22 & 8,37 & 3,33 & 51,40 \\
\hline
\end{tabular}


910 Jurnal e-Biomedik (eBM), Volume 1, Nomor 2, Juli 2013, 907-913

\section{Uji Kenormalan Data}

Tabel 3. One-Sample Kolmogorov-Smirnov Test

\begin{tabular}{llllll}
\hline & & pretest & posttest & pretest & posttest \\
& & LDL & LDL & HDL & HDL \\
\hline $\mathrm{N}$ & & 30 & 30 & 30 & 30 \\
Normal Parameters ${ }^{\mathrm{a}, \mathrm{b}}$ & Mean & 170.20 & 134.73 & 35.93 & 39.53 \\
& Std. Deviation & 46.164 & 29.368 & 6.313 & 10.109 \\
\multirow{2}{*}{ Most Extreme Differences } & Absolute & .121 & .091 & .096 & .132 \\
& Positive & .087 & .091 & .096 & .132 \\
& Negative & -.121 & -.070 & -.075 & -.094 \\
Kolmogorov-Smirnov Z & & .665 & .497 & .525 & .724 \\
Asymp. Sig. (2-tailed) & & .768 & .966 & .946 & .670 \\
\hline
\end{tabular}

a. Test distribution is Normal.

b. Calculated from data.

\section{Kadar kolesterol HDL}

Kadar kolesterol HDL mengalami peningkatan. Pada pretest, subjek mempunyai kadar kolesterol HDL sebesar 35,93 mg/dl yang kemudian meningkat sehingga pada posttest, subjek mempunyai kadar kolesterol HDL sebesar 39,53 mg/dl.

\section{Kadar kolesterol HDL dengan uji t-paired}

Signifikansi pada t-paired test kadar $H D L$ probabilitasnya 0,022 . Oleh karena $0,022<0,05$, maka nilai signifikansinya bermakna. Dapat disimpulkan bahwa kadar kolesterol HDL sebelum dan sesudah melakukan senam bugar lansia relatif tidak sama atau kegiatan senam bugar lansia tersebut efektif dalam meningkatkan kadar kolesterol HDL secara nyata.

\section{Kadar kolesterol $L D L$}

Kadar kolesterol LDL mengalami penurunan. Pada pretest, subjek mempunyai kadar kolesterol $L D L$ sebesar 170,20 mg/dl yang kemudian menurun sehingga pada posttest, subjek mempunyai kadar kolesterol LDL sebesar 134,73 mg/dl.

Tabel 4. Kadar $H D L$

\begin{tabular}{llllll}
\hline & & Mean & $\mathrm{N}$ & Std. Deviation & Std. Error Mean \\
\hline Pair 1 & pretest HDL & 35.93 & 30 & 6.313 & 1.153 \\
& posttest HDL & 39.53 & 30 & 10.109 & 1.846 \\
\hline
\end{tabular}

Tabel 5. t-Paired Samples Test Kadar HDL

Paired Differences

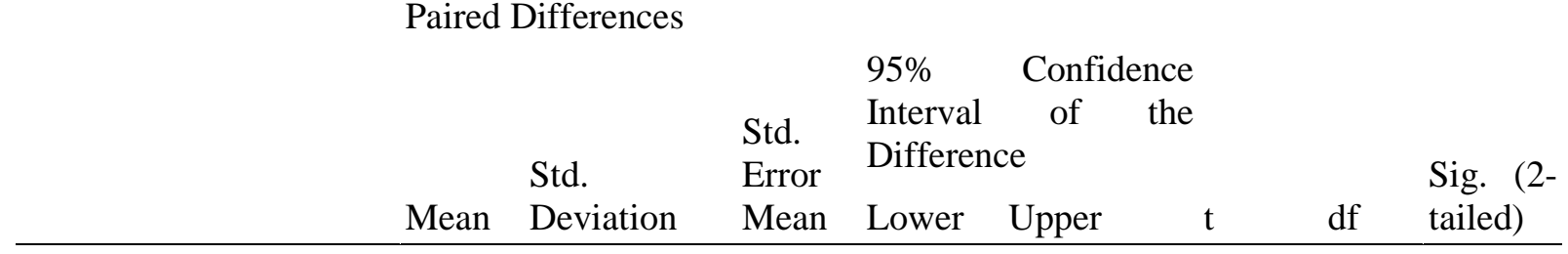


Tabel 5. t-Paired Samples Test Kadar HDL

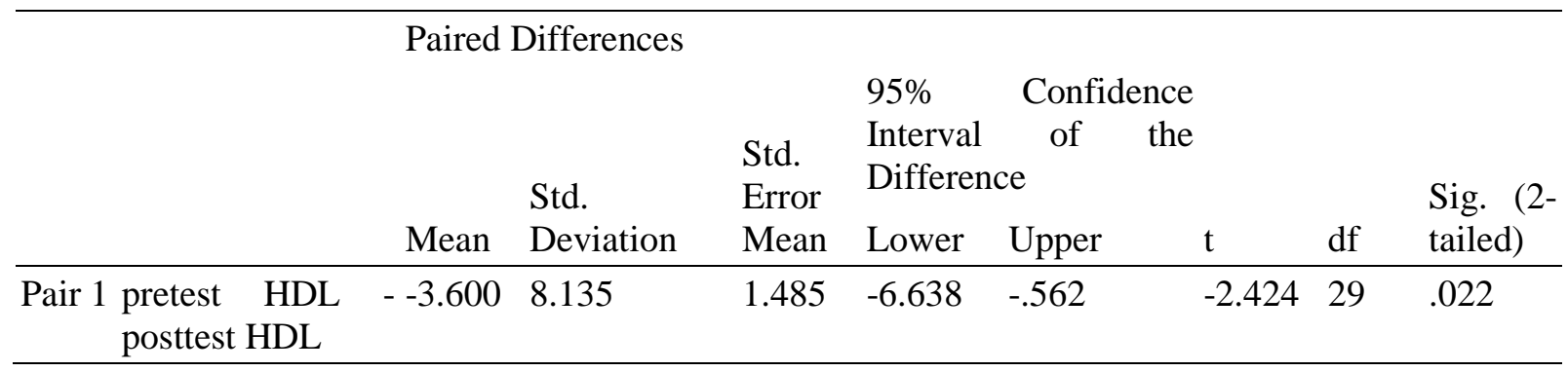

Tabel 6. Kadar $L D L$

\begin{tabular}{|c|c|c|c|c|c|}
\hline & & Mean & $\mathrm{N}$ & Std. Deviation & Std. Error Mean \\
\hline \multirow[t]{2}{*}{ Pair 1} & pretest & 170.20 & 30 & 46.164 & 8.428 \\
\hline & posttest & 134.73 & 30 & 29.368 & 5.362 \\
\hline
\end{tabular}

Tabel 7. Paired Samples Test Kadar LDL

\begin{tabular}{|c|c|c|c|c|c|c|c|}
\hline & \multicolumn{7}{|c|}{ Paired Differences } \\
\hline & \multirow[b]{2}{*}{ Mean } & \multirow{2}{*}{$\begin{array}{l}\text { Std. } \\
\text { Deviation }\end{array}$} & \multirow{2}{*}{$\begin{array}{l}\text { Std. Error } \\
\text { Mean }\end{array}$} & \multicolumn{2}{|c|}{$\begin{array}{l}\text { 95\% Confidence Interval } \\
\text { of the Difference }\end{array}$} & \multirow[t]{2}{*}{ df } & \multirow[t]{2}{*}{ df tailed) } \\
\hline & & & & Lower & Upper & & \\
\hline $\begin{array}{ll}\text { Pair } & \text { pretest } \mathrm{LDL} \\
1 & \text { posttest LDL }\end{array}$ & -35.467 & 40.092 & 7.320 & 20.4 & 50.437 & 4.84529 & .000 \\
\hline
\end{tabular}

\section{Kadar kolesterol $L D L$ dengan uji t-paired}

Signifikansi pada t-paired test kadar $L D L$ probabilitasnya 0,000 . Oleh karena $0,000<0,05$, maka nilai signifikansinya bermakna. Dapat disimpulkan bahwa kadar kolesterol LDL sebelum dan sesudah melakukan senam bugar lansia relatif tidak sama atau kegiatan senam bugar lansia tersebut efektif dalam menurunkan kadar kolesterol $L D L$ secara nyata.

\section{BAHASAN}

\section{Kadar kolesterol HDL}

Dalam hasil penelitian ini dapat dilihat terjadi peningkatan kadar kolesterol $H D L$ yang bermakna $(p=0,022)$. Hasil penelitian ini memberikan bukti yang konsisten dengan penelitian-penelitian yang sebelumnya. Menurut penelitian Hartini dkk (2009), olahraga dapat meningkatkan HDL yang membantu proses metabolisme dan menurunkan kadar $L D L$. Pada tabel 2 dapat dilihat terdapat penurunan $H D L$ pada sebagian kecil subjek. Hal ini dikarenakan adanya asupan lemak jenuh yang rendah dan merokok pada subjek tersebut yang secara teoritis dari beberapa penelitian sebelumnya dapat mengakibatkan penurunan kadar kolesterol $H D L$ dan peningkatan kadar $L D L$. Kadar kolesterol HDL yang normal adalah $>40 \mathrm{mg} / \mathrm{dl}^{2}$.

Mekanisme bagaimana olahraga dapat meningkatkan kadar kolesterol HDL belum sepenuhnya diketahui tetapi diyakini terdapat hubungan setidaknya dalam meningkatkan ekspresi dari lipoprotein lipase (LPL). Aktifitas LPL sudah dikenal memiliki hubungan positif dengan kadar kolesterol dan olahraga juga diketahui dapat meningkatkan aktifitas LPL trigliserid. LPL 
adalah suatu enzim yang memiliki peranan penting dalam metabolisme lipoprotein dimana enzim ini dapat masuk ke dalam endothelium melalui heparin sulphate proteoglikan, kemudian mengkatalisis proses hidrolisis dari trigliserida pokok (TGs) yang berasal dari triglyceride-rich lipoprotein (TGRL), seperti kilomikron dan $V L D L$, dan menghasilkan asam lemak bebas dan gliserol ke dalam aliran darah. Asam lemak ini menjadi sangat penting sebagai sumber bahan bakar bagi otot-otot terutama dalam waktu yang cukup lama ${ }^{6}$.

\section{Kadar kolesterol $L D L$}

Dalam hasil penelitian ini dapat dilihat pada tabel terjadi penurunan kadar kolesterol $L D L$ yang bermakna $(\mathrm{p}=0,000)$. Menurut penelitian Edyanto dkk (2012), menunjukkan bahwa aktifitas fisik yang teratur memberikan penurunan yang bermakna terhadap kadar serum kolesterol $L D L{ }^{7}$

Pada Tabel 2 dapat dilihat peningkatan kadar kolesterol $L D L$ pada sebagian kecil subjek. Hal ini dikarenakan terdapat peningkatan kadar kolesterol HDL pada subjek yang bersangkutan. Seperti yang dijelaskan sebelumnya, asupan lemak jenuh dan merokok berpengaruh terhadap peningkatan kadar kolesterol $L D L$ dan penurunan kadar kolesterol $H D L$. Kadar kolesterol $L D L$ yang normal adalah $<130 \mathrm{mg} / \mathrm{dl}^{2}{ }^{2}$

Penurunan kadar kolesterol $L D L$ ini disebabkan adanya kandungan asam-asam lemak tak jenuh $(H D L)$ yang tinggi, seperti asam lemak tak jenuh tunggal (asam oleat) dan asam lemak tak jenuh ganda (asam linoleat). HDL dapat menurunkan kadar kolesterol dengan cara merangsang perubahan ester kolesterol menjadi asam empedu dan dikeluarkan melalui saluran empedu. Selain itu, dapat meningkatkan pembentukan reseptor $L D L$, sehingga proses katabolisme $L D L$ dalam darah segera didistribusikan ke dalam jaringan. HDL pun akan menurunkan kadar kolesterol plasma darah karena $H D L$ dalam hati tidak diubah menjadi $L D L$ dan VLDL tetapi cenderung mengalami oksidasi menghasilkan asam empedu. ${ }^{8}$

\section{SIMPULAN}

Dari hasil penelitian diatas dapat ditarik beberapa kesimpulan, yaitu:

1. Olahraga (senam bugar lansia) sangat bermanfaat bagi kesehatan fisik dan kejiwaan apabila dilakukan secara rutin dan teratur dengan program yang benar.

2. Senam bugar lansia dapat menurunkan kadar $L D L$ kolesterol.

3. Senam bugar lansia dapat menaikkan kadar HDL kolesterol.

\section{SARAN}

Berkaitan dengan hasil penelitian ini, dimana sebagian besar subjek memiliki profil lipid darah yang kurang baik, Penulis menyarankan kepada masyarakat terutama pada lansia bahwa melakukan olahraga atau aktifitas fisik sangatlah penting dan harus tetap dilanjutkan secara teratur dan terusmenerus karena memberikan manfaat yang baik bagi fisik maupun kejiwaan.

\section{UCAPAN TERIMA KASIH}

Ucapan terima kasih disampaikan pada dr. J. J. V. Rampengan, AIFM, AIFO, dr. H.I.S. Wungouw, Ms.App.Sc, M.Med.Ed, AIFM, AIFO, dr. D.H.C. Pangemanan, M.kes, AIFM, lansia yang ada di BPLU Manado, instruktur senam bugar lansia, Lab Patra, dan pada semua pihak yang baik secara langsung maupun tidak langsung telah menumbuhkan ide/gagasan dalam pemikiran penulisan sehingga dapat menyelesaikan artikel ini.

\section{DAFTAR PUSTAKA}

1. Thristyaningsih S, Probosuseno, Astuti $H$. SBL Berpengaruh Terhadap Daya Tahan Jantung, Paru, Status Gizi, dan Tekanan Darah. Jurnal Gizi Klinik Indonesia. 2011:Vol.8. p. 14-22.

2. Hartini S, Mulyanti. Efektifitas Senam Lansia Terhadap Penurunan Kadar Kolesterol Darah Pada Lansia Merokok [skripsi]. Surakarta: STIKes Kusuma Husada; 2009.

3. Adam JM. Dislipidemia. In: Sudoyo AW, Setiyohadi B, Alwi I, Simadibrata M, Setiati 
S, editors. Buku Ajar Ilmu Penyakit Dalam Edisi 5. Jakarta Pusat: Interna Publishing; 2009. p. 1984-92.

4. Akmal H. Perbedaan Asupan Energi, Protein, Aktifitas Fisik dan Status Gizi Antara Lansia yang Mengikuti dan Tidak Mengikuti Senam Bugar Lansia [skripsi]. Semarang: Universitas Diponegoro; 2012.

5. Rifdhi. Pengaruh SBL Terhadap Activity of Daily Living [thesis]. Jakarta: Universitas Trisakti; 2012.
6. Wijaya A, Ngahu R, Pascana Y, Saribanon S. Hubungan Olahraga Dengan Kadar HDL Dalam Tubuh [skripsi]. Surakarta: Universitas RSUD DR. Moewardi; 2012.

7. Edyanto E, Puruhita N. Perbedaan Kadar Kolesterol LDL dan HDL Pada Wanita Vegan dan Non Vegan [skripsi]. Semarang: Universitas Diponegoro; 2012.

8. Tuminah S. Peran Kolesterol HDL Terhadap Penyakit Kardiovaskuler Dan DM [makalah]. Jakarta: Badan Litbangkes, Departemen Kesehatan RI; 2009. 